\title{
EFFECT OF CORPORATE PERFORMANCE ON INTANGIBLE ASSETS OF HEALTHCARE FIRMS IN NIGERIA
}

\author{
OGBU, Moses Onwe \\ Department of Accountancy, Faculty of Management Sciences \\ Enugu State University of Science \& Technology (ESUT) \\ Onyekwelu, Uche Lucy Ph.D. \\ Department of Accountancy, Faculty of Management Sciences \\ Enugu State University of Science \& Technology (ESUT) \\ Anewe, Y. Paulinus \\ Department of Accountancy, \\ Benue State Polytechnic, Ugbokolo \\ Correspondence Author: OGBU, Moses Onwe,
}

\begin{abstract}
The study examines the effect of corporate performance on intangible assets of healthcare firms in Nigeria:It also examines the effect of Net Operating Income (NOI), Profit After Tax (PAT) and Earning Per Share (EPS) on intangible assets of the selected firms. Three firms were selected through simple random sampling technique.Data for the study was extracted from ten (10) years (2007-2016) annual report and accounts of the four health care firms in Nigeria. The data were subjected to Pearson Moment Correlation Analysis, Regression Analysis and two-tailed analysis of variance (ANOVA). Findings reveal that there is a negative and insignificant relationship between net operating income and intangible assets, Profit After Tax does not have significant effect on intangible assets of health care firms in Nigeria. And EPS does not have significant effect on intangible assets of health care firms in Nigeria. Based on the findings the researcher recommends that actions to improve on the net operating income, address the issue of tax evasion, appropriate more to providers of capital be stepped up by the management of healthcare firms in Nigeria.
\end{abstract}

Keywords: Intangible Assets, NOI, PAT, EPS.

\subsection{Introduction}

Intangible assets also known as non-physical assets such as brands, human capital, managerial expertise have no accepted standard for appraising their worth (Caruso, 2008).Dorota and Andrzej (2014) opined that intangible assets of hospitals include knowledge, personnel skills, organizational structures and procedures and hospital's reputation.Moldchik, Shakina and Bykova (2012) in Dorota and Andrzej (2014) assert that the value of intangible assets has potential character.That is to say that they can be used for building the value of the firm.

Magdaliena( (2009) states that there are different terms used to coin intangible resources and intellectual capital and intellectual property. She further stated that the term is taken from accounting theory. Handy(1989) in Dimitros, Zeljko and Charalampos, (2009) submit that intellectual assets are three or four times the tangible book value of a company. Van Burren (1999) in Dimitrous et al (2009) suggested that intangible assets represent more than twothirds of the corporate value. Osborne (1998) also indicated that 80 percent of a company's value is not tangible. 
As with other organisations, among the most valuable assets of a health care organization are the knowledge, skills and experiences of their leaders and professionals. These intangibles resources, couple with the value derived from internal capabilities and external relationships, constitute the intellectual capital (IC) of healthcare organizations and systems (Evans, Brown and Baver, 2015).

Needless to say, intangible assets are not sufficiently visible, not properly controlled. Despite their great importance, most of the financial statements present only a simplified image of the company and in order to appreciate its true value it is vital to also analyse its intangible assets, which in many situations are not accurately valuated.

The contribution of intangible assets to the corporate performance cannot be over emphasized as healthcare firms in Nigeria have great stocks of intangible assets.

This paper therefore assessed the variable components of health care firm's financial statements such as net operating income, PAT, EPS and share capital impact or affect the intangible assets of some selected healthcare firms quoted on the Nigerian Stock Exchange.

\subsection{Statement of the Problem}

Intangible assets contribute in no small way to the corporate performance of organizations. In spite of this, not much attention is given to the intangible assets in most of the financial statements presented by many organizations in Nigeria. Healthcare firms in Nigeria suffer from this lack of disclosure of intangible assets and their significance in corporate government. An understanding of the relationship between net operating income, PAT, EPS and the share capital is very vital to management, shareholders, the government and the general public. This however is lacking in the healthcare sector of our economy. Most of the existing literatures capture scenarios in advanced countries. We have also discovered through reviewed literature that variables such as NOI, PAT and EPS have not been explored. This research therefore embarked upon in an attempt to determine the relationship between NOI, PAT, EPS and share capital and intangible assets in healthcare firms in Nigeria.

\subsection{Objectives of the Study}

The general objective of this study is to appraise the effect of corporate performance on intangible assets of healthcare firms in Nigeria. The specific objectives of the study are:

1. To examine the effect of net operating income on intangible assets of healthcare firms in Nigeria.

2. To verify the effect of Profit after Tax on intangible assets of healthcare firms in Nigeria.

3. To ascertain the effect of Earnings per Share on intangible assets of health firms in Nigeria.

\subsection{Research Questions}

1. How does net operating income affect intangible assets of healthcare firms in Nigeria?

2. Does PAT have effect on intangible assets of healthcare firms in Nigeria?

3. What effect does EPS have on the intangible assets of healthcare firms?

\subsection{Statement of Hypotheses}

The following hypotheses are stated in their null form guided the study:

1. Net operating income does not have significant effect on intangible assets of healthcare firms in Nigeria.

2. Profit after tax does not have significant effect on the intangible assets of healthcare firms in Nigeria.

3. Earning per share does not have significant effect on the intangible assets of healthcare firms in Nigeria. 


\subsection{Scope of the Study}

The content coverage of this study is corporate performance and its effect on intangible assets of some selected healthcare firms in Nigeria, namely May and Baker, Ekocorp, Fidson Healthcare and Pharma-Deko PLC, using ten (10) year 2007 - 2016 financial statements.

\section{Review of Related Literature}

\subsection{Conceptual Review}

\subsubsection{Intangible Assets}

These are also referred to as invisible, non-physical or intellectual capital (Caruso, 2008). Dumitrescu, A. (2012) describes intangible assets to include the capacity for the innovation of a company, the intellectual capacity of employees, the know-how, the management practices, the organisation within the company, the human resource management, the owned patents and technologies, the technological skills, the trade marks, the awareness of each brand, the internal good will, the relationship with customers, the customers loyalty, etc. The International Accounting Standards Board (IASB) defines intangible assets as "identifiable non-monetary assets without physical substance. IASB classified intangible assets into the following categories:

Computer software, Patents, Copyright, Motion picture films, Customer lists , Mortgage serving rights, Licenses, Import quotas, Franchises, Franchises, Customers, Supplier relationship, Marketing rights.Intangible resources are all those resources a firm possesses that are invisible in character, but contribute to increased income and value generating process of the company (Kapelko, 2009). Hendriksen and Van Breda (1999) in Chiarello et al (2013) define intangible assets as "the assets that cannot be touched because they have no body". They are sources of value without physical substance.

\subsubsection{Corporate Performance}

Cochran and Wood (1984) in Chiarello et al (2013) opined that corporate performance can be looked at form two angles.

These first one regards the return to the investor while the second one refers to the accounting return (profit). Bonaventura, Silva and Bandeira-De-Mello (2012) in Chiarello et al (2013) identified ROA, ROE, Sales growth, return on sales, contribution margin, firms risk, ROCE, operating income cash flow and share earnings as measures of financial performance

\subsubsection{Profit after Tax (PAT)}

This is the net profit earned by the company after deducting all expenses like interest, depreciation and tax. It is that income that is left for distribution or appropriation after all the expenses including tax have been taken care of. It is denoted by the formula.

\section{PAT $=$ Total Revenue - Total expenses}

Business Dictionary (www.businessdictionary.com) defines PAT as the amount earned by a business after all taxation related expenses have been deducted. The PAT is often a better assessment of what a business is really earning and hence can use in its operation than its total revenue. It is the amount by which income from sales is larger than all expenditure (Web Finance Incorporated, 2018)

\subsubsection{Net Operating Income(NOI)}

www.investopedia.com defines NOI as a before-tax figure which excludes principal and interest payments on loans, capital expenditures, depreciation and amortization. Net operating income is considered less vulnerable to manipulation than some other figures because it can only be increased by raising rents and associated fees or by decreasing reasonably necessary operating income. The net operating income helps owners and potential owners to calculate 
several helpful ratios such as debt coverage ratio, cash return on investment and total return on investment.

\subsubsection{Earning Per Share (EPS)}

This ratio measures the amount of earnings that is attributed to one share. It is a company's net income expressed on a per share basis. The number of shares that is utilized is not the authorized share capital but the number of shares that is issued and paid up as at the close of the record date. It is given by the formula.

EPS $=\frac{\text { Net income }- \text { preferred dividend }}{\text { Weighted number of shares outstandings }}$

\subsection{Empirical Review}

Widiantoro (2012) examines the impact of intangible investment towards a company's health and Company agency problem in Indonesia. The objective of the study was to measure the impact of intangible assets investment toward companies' financial health and agency problem. Thirty (30) Indonesian stock listed companies were studied looking at market value, dividend policy, solvency ratio, intangible value and company performance as empirical research parameter. Results reveal a significant relationship between the amount of intangible assets and the market value of companies.

The effect of intangible assets, financial performance and financial policies on the firm value was an empirical research embarked upon by Gamayuni (2015). The purpose of the study was to test empirically the relationship between intangible assets, financial policies and financial performance to the firm value at going- public company in Indonesia. Path analysis was used to ascertain the relationship between the variables in the year 2007-2009. The result provides empirical evidence that intangible assets, financial policies, financial performance have significant influence to the firm value simultaneously. Results also show that intangible assets have no significant financial policies but have positive and significant influence to financial performance (ROA) and firm value. The study concludsed that intangible assets have a significant and positive effect on firm value. It was recommended that accounting standards be concerned about this.

Chiarello, Pletsch, Dasiva and Dasilva(2013) investigated financial performance, intangible assets and value creation in Branzilian and Chilean information technologies companies. Descriptive statistics analysis, t-test and Pearson's correlation were used for the analysis of the data. Result confirm that Chilean companies disclose more intangible assets and make greater value through reaching good results in financial performance.

Intellectual capital and business performance: an empirical study for the Greek listed companies was an investigation carried out by Maditionos, Dervic, and Tsaririchiis, (2009). The aim of the study was to empirically examine four elements of intellectual capital (human capital, customer capital, structural capital and innovation capital) and their relationship with business performance in Attens Stock Exchange. Confirmatory Factor Analysis and Structural Equation Model were used as statistical methods to analyse the data. It was found that:

a. Human capital is important and positively associated to customer capital in both service and non-service.

b. Customer capital has influence in structural capital rather than in non-service industries.

c. Innovation Capital seems to have an important and positive relationship to structural, regardless of the industry type.

Evans Brown and Baker (2015) investigated capital in the healthcare sector: a systematic review and critique of the literature. The objective of the study was to review and criticize the existing literature on intellectual capital in the healthcare sector. 
Kapelko(2009) carried out a study on intangible assets and firm efficiency: international analysis in the textile and apparel industry.The objective was to determine the role that intangible assets play in the efficiency of firms. The study areas were companies from the US, Japan, China, Korea, Taiwan, Germany and the UK. Data Envelopment Analysis (DEA) method was used to analyse the data. The result indicates that textile and apparel firms need to invest in intangible assets.

Factors influencing healthcare service quality was another research work embarked on by Mosadeghrad A. M. (2014). The purpose of the study was to identify factors that influence healthcare quality in the Iranian context. Exploratory in-depth individual and focus group interviews were conducted with 222 healthcare stakeholders including providers, managers, policy-makers and payers to identify factors affecting the quality of healthcare services provided in Iranian healthcare organisations. Results indicate that quality in healthcare is a production of cooperation between the patient and the healthcare provider in a supportive environment. The author concluded that the article contributes to healthcare theory and practice by developing a conceptual frame work that provides policy-makers and managers a practical understanding of factors that affect healthcare service quality.

Vodak (2011) investigated the importance of intangible assets for making the company's value. The objective was to point out the interconnection of making the company's value and tangible assets emphasizing the intellectual and social capital when using the outputs of the Balance Score-card methodology. The important output from the study was the realization of the fact that the innovations in perception of the importance of the intellectual capital and its development and cultivation in the company are the most important for companies.

Crema and Nosella (2015) embarked on empirical research on intangible assets management and evaluation: evidence from small and medium-sized enterprises (SMEs). The objective of the study was to develop a modular, multi-purpose, forward-looking tool test in three small firms in Italy. The results of their analysis show that the model's application in the companies was successful in enhancing managers' awareness about intangible assets and in improving the management of these assets.

Measuring intangibles: managing intangibles for tangible outcomes in researching an innovation was a study conducted by Carayannis(2014). The aim was to identify intangible benefits, the causes and effect relationships and the applicability of existing metrics to these intangible. Findings reveal that a good management of a firm's intangible contributes positively and significantly to the tangible outcomes of a firm's value.

Dumitrescu (2012) in a study titled "intangible assets: are resources sufficiently visible and properly controlled?", opined that intangible assets create value for the company. The aim of the article was to reveal how Romanian companies disclose information about the elements of intangible assets.

A comparative analysis of the information on tangible assets presented in the Annual Reports by a sample of Romanian companies listed at Bucharest Stock Exchange was done. The study reveals that many Romanian companies listed at Bucharest Stock Exchange do not grant enough importance to disclose detailed information on the intangible assets in their Annual Reports.

Cordova, Duran and Gahindo(2012) investigated the "evaluation of intangible assets and best practice in a medium-sized port community. The aim was to analyse the main factors involved in the knowledge management of different actors participating in a Chilean port community.

Interview method was used to source data. The results of the assessment identified the main critical factors in knowledge management, transference, dissemination, collaboration and team work, storage and best practices. 


\section{METHODOLOGY}

\subsection{Research Design}

The design of the study is a descriptive design (ex-post facto ). It described the events in their naturally occurring conditions, i.e. making use of life data. Data are collected, organized and analysed and the results described as they exist without interference.

\subsection{Sources of Data}

The data used for the study are secondary data (life data) generated from journals, annual reports and text books. The researcher also made use of the internet.

\subsection{Area of Study}

The study was carried out in Nigeria on the healthcare sector using four pharmaceutical companies-May and Baker, Ekocorp, Fidson Healthcare and Pharma-Deko PLC as case study. The annual report for ten (10) consecutive years (2007-2016) were used.

\subsection{Population and Sample}

The population of the study is the healthcare sector in Nigeria, while the sample is May and Baker, Ekocorp, Fidson Healthcare and Pharma-Deko PLC selected through simple random sampling.

\subsection{Analytical Method/ Technique}

The researcher made use of Pearson moment correlation Analysis, Regression Analysis and two-tailed Analysis of variance (ANOVA) The model for the regression analysis is shown below.

$I A=F(N O I+P A T+E P S)$

Specifically in econometric format, we have:

$I A=a 0, a 1, a 2, a 3, a 4=$ intangibleassets represents dependent variable intercept term, effect on NOI (Net Operating Income), PAT (Profit After Tax) and EPS (Earnings Per Share) are the independent variables

\section{Significance level $=0.05$}

Decision rule: Reject null hypothesis if $\mathrm{p}$-calculated value is greater than $\mathrm{p}$ - critical value

\section{PRESENTATION AND ANALYSIS OF DATA}

\subsection{Presentation of Data}

Table 4.1: Aggregate of data from selected Pharmaceutical companies [see Appendix]

\begin{tabular}{|c|c|c|c|c|c|}
\hline Year & $\begin{array}{c}\text { Intangible } \\
\text { Assets } \\
\text { N'000 }\end{array}$ & $\begin{array}{c}\text { Share capital } \\
\mathbf{N} \text { '000 }\end{array}$ & $\begin{array}{c}\text { Net Operating } \\
\text { Income } \\
\mathbf{N} \mathbf{0 0 0}\end{array}$ & $\begin{array}{c}\text { PAT } \\
\mathbf{N} \text { 000 }\end{array}$ & EPS \\
\hline 2007 & 80,633 & $250,762,113$ & $92,067,565$ & $74,830,276$ & 0.80 \\
\hline 2008 & 67,296 & $251,422,932$ & $103,932,760$ & $67,573,841$ & -132.70 \\
\hline 2009 & 67,296 & $251,422,932$ & $95,941,665$ & $65,771,615$ & -374.33 \\
\hline 2010 & 67,296 & $251,422,932$ & $75,035,608$ & $67,539,543$ & 585.06 \\
\hline 2011 & 67,296 & $250,590,213$ & $81,848,210$ & $72,678,541$ & $66 . .27$ \\
\hline 2012 & 67,296 & $251,422,932$ & $172,239,234$ & $131,764,436$ & 815.52 \\
\hline 2013 & 968,718 & $252,913,256$ & $-188.926,646$ & $-152,729,896$ & -123.32 \\
\hline 2014 & $2,531,355$ & $252,913,256$ & $186,715,091$ & $186,715,091$ & 167.89 \\
\hline 2015 & $4,622,080$ & $252,913,256$ & $175,627,180$ & $175,627,180$ & $370 . .42$ \\
\hline 2016 & $1,825,189$ & $252,913,256$ & $97,127,181$ & $97,127,181$ & -59.85 \\
\hline
\end{tabular}

Source: Annual reports of May \& Baker, Ekocorp, Fidson Health Care and Pharma-Dekoplc 


\subsection{Analysis of Data}

\subsubsection{Objective 1}

Model Summary

\begin{tabular}{|l|r|r|r|r|}
\hline Model & \multicolumn{1}{|c|}{ R } & \multicolumn{1}{c|}{ R Square } & Adjusted R Square & \multicolumn{1}{c|}{$\begin{array}{c}\text { Std. Error of the } \\
\text { Estimate }\end{array}$} \\
\hline 1 & $.490^{\mathrm{a}}$ & .241 & .146 & 1422960.98172 \\
\hline
\end{tabular}

a. Predictors: (Constant), NOINCOME

The degree of association between Net Operating Income and intangible assets is positive and weak at $r=0.490$. The analysis also reveals that the coefficient of determination $r^{2}=0.241$. It implies that net operating income explains only $24.1 \%$ of the variations in intangible assets during the period.

\section{Hypothesis 1}

$\mathbf{H}_{01}$ : Net operating income does not have significant effect on intangible assets of health care firms in Nigeria

Decision rule: Accept $\mathrm{H}_{01}$ if $\mathrm{p}$-value $>0.05$, otherwise reject.

ANOVA $^{\mathrm{a}}$

\begin{tabular}{|c|c|c|c|c|c|}
\hline Model & Sum of Squares & Df & Mean Square & $\bar{F}$ & $\overline{p \text {-value }}$ \\
\hline Regression & 5129520161805.025 & 1 & 5129520161805.025 & 2.533 & $.150^{\mathrm{b}}$ \\
\hline Residual & 16198543643931.475 & 8 & 2024817955491.434 & & \\
\hline Total & 21328063805736.500 & 9 & & & \\
\hline
\end{tabular}

a. Dependent Variable: INTASSETS

b. Predictors: (Constant), NOINCOME

Remarks: Since p-value $=0.150>0.05$, we accept the null hypothesis and conclude that net operating income did not have significant effect on intangible assets of health care firms in Nigeria during the years under study.

$$
\text { Coefficients }^{\mathrm{a}}
$$

\begin{tabular}{|c|c|c|c|c|c|c|}
\hline \multirow{2}{*}{\multicolumn{2}{|c|}{ Model }} & \multicolumn{2}{|c|}{ Unstandardized Coefficients } & \multirow{2}{*}{$\begin{array}{c}\begin{array}{c}\text { Standardized } \\
\text { Coefficients }\end{array} \\
\text { Beta }\end{array}$} & \multirow[t]{2}{*}{$\mathrm{T}$} & \multirow[t]{2}{*}{ p-value } \\
\hline & & B & Std. Error & & & \\
\hline \multirow{2}{*}{1} & (Constant) & -403988.256 & 1010694.948 & & -.400 & .700 \\
\hline & NOINCOME & .013 & .008 & .490 & 1.592 & .150 \\
\hline
\end{tabular}

Dependent Variable: INT ASSETS

The regression model for this objective is as follows:

$\mathrm{Y}_{\mathrm{i}}=-403988.256+0.013 \mathrm{X}_{\mathrm{i}}+\mathrm{e}_{\mathrm{i}}$

This implies that net operating income made a fixed but negative change to intangible assets during the period while it also contributed negligibly or insignificantly to annual variation in intangible assets. 


\subsubsection{Objective 2}

\section{Model Summary}

\begin{tabular}{|l|r|r|r|r|}
\hline Model & \multicolumn{1}{|c|}{ R } & R Square & Adjusted R Square & $\begin{array}{c}\text { Std. Error of the } \\
\text { Estimate }\end{array}$ \\
\hline 1 & $.411^{2}$ & .169 & .065 & 1488211.00778 \\
\hline
\end{tabular}

a. Predictors: (Constant), PAT

The model summary of the analysis also indicates that there is a positive but weak relationship between Profit after tax and intangible assets as the variation in intangible assets is explained up to $16.9 \%$ only by profit after tax of the health care firms. This is a very insignificant value.

\section{Hypothesis 2}

$\mathbf{H}_{\mathbf{0 2}}$ : Profit after tax does not have significant effect on intangible assets of health care firms in Nigeria

Decision rule: Accept $\mathrm{H}_{02}$ if $\mathrm{p}$-value >0.05, otherwise reject.

\begin{tabular}{|c|c|c|c|c|c|}
\hline \multicolumn{6}{|c|}{ ANOVA“ } \\
\hline Regression & 3609887776427.479 & 1 & 3609887776427.479 & 1.630 & $.238^{\mathrm{b}}$ \\
\hline Residual & 17718176029309.020 & 8 & 2214772003663.627 & & \\
\hline Total & 21328063805736.500 & 9 & & & \\
\hline
\end{tabular}

a. Dependent Variable: INTASSETS

b. Predictors: (Constant), PAT

Decision: Since p-value $=0.238>0.05$, we accept $\mathrm{H}_{02}$ and conclude that profit after tax did not have significant effect on intangible assets of health care firms in Nigeria in the period under consideration.

Coefficients $^{\mathrm{a}}$

\begin{tabular}{|c|c|c|c|c|c|}
\hline \multirow[t]{2}{*}{ Model } & \multicolumn{2}{|c|}{ Unstandardized Coefficients } & Standardized & \multirow[t]{2}{*}{$\mathrm{T}$} & \multirow[t]{2}{*}{ p-value } \\
\hline & $\mathrm{B}$ & Std. Error & Beta & & \\
\hline (Constant) & 501955.581 & 629880.889 & & .797 & \\
\hline PAT & .007 & .005 & 4 & 1.277 & \\
\hline
\end{tabular}

Dependent Variable: INTASSETS

The simple regression equation for this relationship is presented as follows:

$\mathrm{Y}_{\mathrm{i}}=501955.581+0.007 \mathrm{X}_{\mathrm{i}}+\mathrm{e}_{\mathrm{i}}$

This implies that PAT made a variable contribution of 0.007 and a fixed contribution of $\mathrm{N} 501,955,81$ to intangible assets of the industry over the period.

\subsubsection{Objective 3}

Model Summary

\begin{tabular}{|l|r|r|r|r|}
\hline Model & R & R Square & Adjusted R Square & \multicolumn{1}{c|}{$\begin{array}{c}\text { Std. Error of the } \\
\text { Estimate }\end{array}$} \\
\hline 1 & $.133^{\mathrm{a}}$ & .018 & -.105 & 1618272.16255 \\
\hline
\end{tabular}

a. Predictors: (Constant), EPS 
The analysis shows that there is a very weak (positive) correlation between EPS and intangible assets. This is confirmed by the coefficient of determination $\left(\mathrm{r}^{2}=0.018\right)$. It implies that EPS was only able to explain the annual variations of the intangible assets at $1.80 \%$. This is quite insignificant.

\section{Hypothesis 3}

$\mathbf{H}_{\mathbf{0 3}}$ : EPS does not have significant effect on intangible assets of health care firms in Nigeria

Decision rule: Accept $\mathrm{H}_{03}$ if $\mathrm{p}$-value > 0.05 , otherwise reject.

\section{ANOVA $^{\mathrm{a}}$}

\begin{tabular}{|c|c|c|c|c|c|}
\hline Model & Sum of Squares & $\mathrm{df}$ & Mean Square & $\mathrm{F}$ & p-value \\
\hline Regression & 377625469152.297 & 1 & 377625469152.297 & .144 & $.714^{b}$ \\
\hline Residual & 20950438336584.203 & 8 & 2618804792073.025 & & \\
\hline Total & 21328063805736.500 & 9 & & & \\
\hline
\end{tabular}

a. Dependent Variable: INTASSETS

b. Predictors: (Constant), EPS

Decision: The test reveals that $p$-value $=0.714$. Since this is greater than 0.05 , we accept $\mathrm{H}_{03}$ and conclude that EPS did not have significant effect on intangible assets of health care firms in Nigeria during the period under study.

Coefficients $^{\mathbf{a}}$

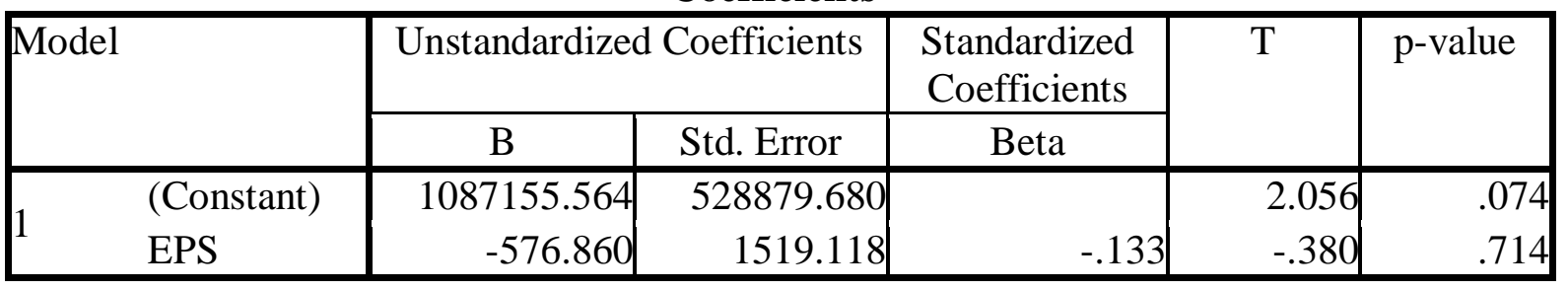

a. Dependent Variable: INTASSETS

The simple regression equation connecting EPS to intangible assets is presented as follows: $\mathrm{Y}_{\mathrm{i}}=1087155.564-576.860 \mathrm{X}_{\mathrm{i}}+\mathrm{e}_{\mathrm{i}}$

The constant value is $\beta_{0}=\mathrm{N} 1,087,155,564$ while $\beta=-567.860$, representing a negative variation in intangible assets due to the contribution by EPS during the period.

\subsection{Summary of Findings}

The following are the findings from this study:

1. Net operating income does not have significant effect on intangible assets of health care firms in Nigeria

2. Profit after Tax does not have significant effect on intangible assets of health care firms in Nigeria

3. Earnings per share does not have significant effect on intangible assets of health care firms in Nigeria

4. Share capital has significant effect on intangible assets of health care firms in Nigeria

\subsection{Conclusion}

The study has been able to achieve its objective through critical analysis of available data based on selected health care firms in Nigeria by adopting the preferred empirical processes of Statistical package for the social science. The study was able to make contributions to knowledge by revealing that the effect of corporate performance extends beyond tangible 
assets to intangible assets of a firm. It is now the expectation of the researcher that concerned firms should make good use of the attendant recommendations for decision making.

\subsection{Recommendations}

The study recommends the following:

1. Management of the health care firms should step up the necessary machinery to improve on the net operating incomes of firms in the health care industry.

2. Management is required to help address the issue of tax evasion in Nigeria economy. The amount of money lost to non-payment of tax revenue in Nigeria is humongous. This has to change.

3. Health care firms should appropriate more to those that have provided the enabling capital or investment in this sector.

4. Health care firms in Nigeria should endeavour to consolidate on the use of share capital and depend less on debt capital as the major source of funding their business.

\section{References}

1. Adeniji, A. A. (2014) Performance management Nigeria, value analyisispublsihers.

2. Akinsulire, O. (2011) Financial management, Nigeria, Ceemol Nigeria limited.

3. Anao, A. R. (2009) Introduction to financial accounting, Malaysia, BHS Book printing.

4. Carayannis, E. G. (2014) Measuring intangibles: managing intangibles for tangible outcomes in research and innovation, International Journal of Nuclear Knowledge Management 070503

5. Caruso D. (2008) The real value of intangibles, retrieved online on the $8^{\text {th }}$ of September, 2018

6. Chambers, R. J. (1966) Accounting, evaluation and economic behaviour, England Chiss, Pretince -Hall

7. Chiarello, (2013) Financial performance, intangible assets and value creation in Brazilian and Chilean information technology companies, economic review of Galicia, 23-24

8. Cordova, F. M. (2016) Evaluation of intangible assets and best practices in a mediumsized port community, retrieved online at www.sciencedirect.com on the $8^{\text {th }}$ of September, 2018

9. Crema, M. \&Nosella, A. (2015) Intangible assets management and evaluation: evidence from SMEs, retrieved online on the $8^{\text {th }}$ of September, 2018

10. Dumitrescu, A. (2012) Intangible assets: are these resources sufficiently visible and properly controlled?,Journal of accounting and management information systems 11 , No. 4 